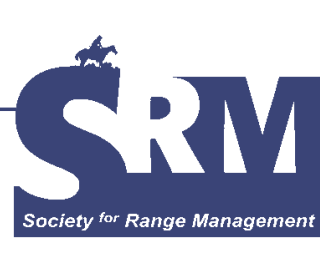

\title{
A History of Working Landscapes: The Altar Valley, Arizona, USA
}

\section{How ranchers have shaped the West-and continue to do so.}

\section{By Nathan F. Sayre}

1

pproaching rangelands as working landscapes begins from the premise that people and the environment shape each other over time. Sustainable ement is therefore not only an ecological but a social process, strongly influenced by local histories of resource use, management, change, and learning. The case of the Altar Valley, Arizona, offers insights into how economics, range science, mental models, and the scale of decision making have shaped ranchers and the landscape over time. In particular, it provides empirical answers to important questions facing range science today: How do scientific knowledge and recommendations affect on-the-ground management? How do ranchers weigh economic, ecological, and cultural goals against one another? What kinds of information do ranchers and other parties need to solve problems and improve stewardship in a rapidly changing West?

The Altar Valley is an approximately 618,000 acre (250,000 hectare) watershed located just north of the United States-Mexico boundary and east of the Tohono O'odham (formerly Papago) Indian Reservation. Elevations range from around 2,460 to $7,710 \mathrm{ft}$ (750 to $2,350 \mathrm{~m}$ ), and average annual precipitation grades from 8 to 24 inches (200 to 600 $\mathrm{mm}$ ) with elevation (Fig. 1). Landownership is a mosaic of state trust (47.5\%) and private lands (11.3\%) in most of the center of the valley, with areas of US Forest Service (11.9\%) and Bureau of Land Management lands (2.3\%) concentrated in the surrounding mountains. The Buenos Aires National Wildlife Refuge (NWR) comprises a large block of land $(18.8 \%)$ in the southern end of the watershed; portions of the Indian Reservation comprise the rest (8.3\%). Thirteen large properties (12 ranches and the Buenos Aires National Wildlife Refuge-which was formed from a ranch in 1985) control 80 percent of the land base in the watershed. The refuge is not grazed by livestock; one ranch is a dude ranch, grazed by horses; the remaining ranches all run cattle. The ranches contain approximately $66 \%$ of the valley's private land.

This article has been peer reviewed.
Although relatively overlooked by scientists, agencies, and environmentalists during the 20th century, the Altar Valley has recently emerged as a focal point in the politics of conservation in Pima County, Arizona. Despite dramatic changes in the structure and composition of vegetation and in watershed function (see below), the area provides habitat to numerous listed threatened or endangered species. Compared to the rest of eastern Pima County, the Altar Valley is also remarkably unfragmented by residential development, although the fringes of metropolitan Tucson (population approximately 1 million) reach right up to its northeastern edge. In consequence, advocates of wildlife and open space conservation are increasingly interested in the activities of the families who own the valley's major ranches. With market prices for private land in the valley ranging upward from $\$ 3,000$ /acre $(\$ 7,410 / \mathrm{ha})$, the incentive to subdivide and the equity values of these ranches are both very high. Recently, Pima County purchased one of the ranches for open space protection and leased it back to the previous owners to manage.

\section{Management History}

The history of management in the Altar Valley is one of reciprocal influence and change in the land and in ranchers' "mental model" of how the land works. ${ }^{1}$ The case study presented here rests on 7 years of participatory research in the area, including extensive interviews, archival research, participant observation, and collaboration with local ranchers on resource conservation projects. ${ }^{2,3}$

\section{Water Development}

Surface water sources were so limited prior to 1885 that the valley saw little human occupation. Ground water supplies are large but very deep. Once well drilling and pumping technologies became available in the late 19th century, water development was rapid. Similarly, the advent of gasoline-powered equipment prompted widespread earthen dam construction after about 1920. The Pima County Agricultural Extension agent promoted water development in the 1920s, and Soil 


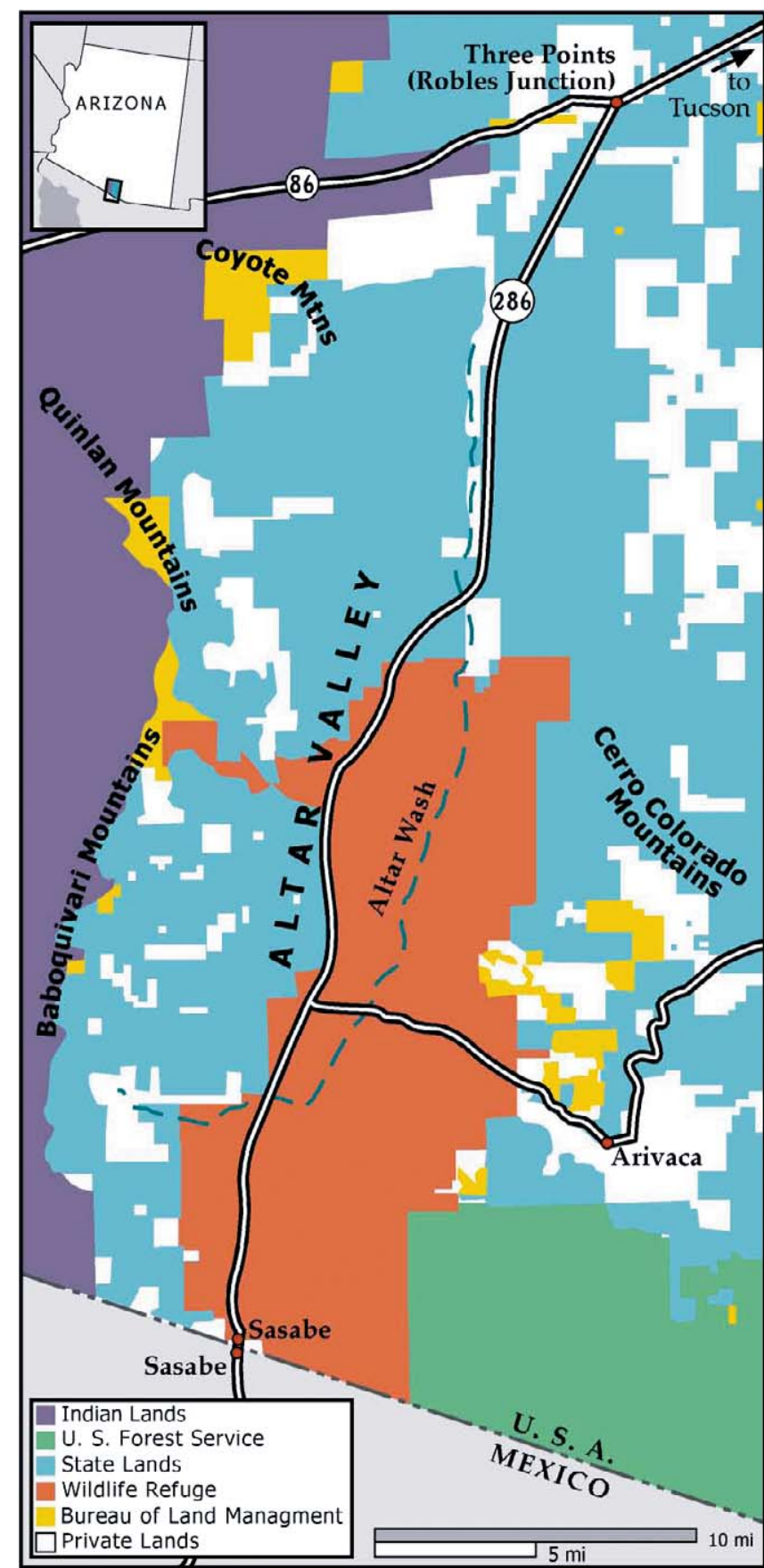

Figure 1. The Altar Valley, Arizona. Despite the mosaic of landownership types, the valley remains almost wholly unfragmented by development. (Map by Darin Jensen.)

Conservation Service programs shared costs for dams, wells, and earthen tanks beginning in the 1930s. One watering point per 4 square miles of land (1,024 ha) is a common ratio on ranches today; the Buenos Aires Ranch (today's refuge), which was large and well-capitalized, achieved 1 reliable watering point per 1,550 acres ( $625 \mathrm{ha}$ ) by 1959 , and nearly twice that ratio by 1983 . Throughout the valley, many watering points are earthen dams, which can be unreliable during droughts. The principal motivation for water developments appears to have been economic: they were a necessary investment required to use naturally occurring forage. Research and extension helped ensure better engineering and design, and cost-sharing programs lessened the private cost of making the improvements.

\section{Fencing and Stocking Rates}

Perimeter fencing of ranches occurred rapidly following the transfer of public domain to state trust land status after 1912, when Arizona attained statehood. Fencing was universally advocated by early range scientists, but like water development, it was probably motivated by economic necessity rather than scientific counsel. The Soil Conservation Service subsidized fence construction beginning in the 1930s. Interior fencing began on some ranches as early as the 1940s, but in most cases it occurred later, in the 1970s and 1980s, when rotational grazing became common. Two large ranches remained without interior fencing (other than along public highways) until the late 1990s.

Stocking rates for the pre-1920 period are difficult to estimate because fences were so rare, but they appear to have been as high as 1 to 2 cows per 10 acres $\left(0.3\right.$ to $\left.0.5 \mathrm{AU} \cdot \mathrm{ha}^{-1}\right), 10$ times greater than typical stocking rates today. Severe droughts in 1891-1893 and 1898-1904 resulted in widespread livestock die-offs, but by the 1910s stocking rates had rebounded to as high as 75 cows per square mile $\left(0.29 \mathrm{AU} \cdot \mathrm{ha}^{-1}\right)$ in the upper end of the valley. This was nearly 4 times the rate recommended by range scientists at the time. ${ }^{4}$ The lower, drier end of the valley did not recover as well from the droughts and carried only 5 to 10 cows per section $\left(0.02-0.04 \mathrm{AU} \cdot \mathrm{ha}^{-1}\right)$ in the 1930 s - similar to rates there today. Stocking rates declined for most of the rest of the century in the higher end of the valley, due more to vegetation change and declining capacity than to enforcement. Today, ranches stock at or below official capacities, which range from 6 to 14 cows per square mile $(0.02-0.06$ $\mathrm{AU} \cdot \mathrm{ha}^{-1}$ ) depending on elevation and rainfall.

\section{Brush Control}

Encroachment of mesquite (Prosopis velutina) into the valley's grasslands appears to have begun in the late 1920s and was recognized as a problem around World War II. Mechanical control techniques began on one valley ranch in the 1950s and were subsequently employed by several neighbors. Overall, some 84,000 acres $(34,000$ ha) of mesquite were mechanically removed on 5 ranches between 1950 and 1980, with about 60,000 acres $(24,291 \mathrm{ha})$ of this on the Buenos Aires Ranch alone. Chemical controls were also attempted but without success. A nonnative perennial, Lehmann lovegrass (Eragrostis lehmanniana), was seeded on much of this area and has become dominant there. Both clearing and seeding were developed by range scientists and actively promoted by extension services at the time. The treatments were economical prior to the oil crisis of the early 1970s; the Buenos Aires treatments were only economical because the owner, a large venture capital firm, could write the costs off against income from other sources. Today, large-scale brush control no longer 
occurs due to high costs and recognition that mesquite will re-establish without follow-up treatments. Lehmann lovegrass is now classified as an invasive species and cannot be used if federal lands or funds are involved.

Fire

Evidence of various kinds suggests that fires occurred, on average, at least once every 10 years in the grassland portions of the valley, and one rancher reports that his grandfather set fires on purpose up until the advent of fences (which were initially built with wooden posts). Heavy grazing and increasingly effective fire suppression policies virtually eliminated fire after that point, facilitating subsequent mesquite encroachment, which in turn limited fire spread. Range scientists have long recognized the role of fire in desert grasslands, but extension services discouraged burning until the 1980s. In an era of metal fence posts, valley ranchers now see fire as an important tool for controlling brush, and prescribed fires are fairly common on the Buenos Aires NWR.

\section{Grazing Management}

Before fencing, herds from different ranches intermingled and moved on their own throughout the valley; mature animals were the primary product. There is evidence that ranchers practiced dormant-season grazing in the 1920s, buying stockers in the fall and selling them in the spring. By 1950, virtually all ranches in the valley had shifted to cow-calf operations using continuous year-around grazing and relatively static stocking rates. This conformed both to range scientists' recommendations and to market demand. Rotational systems began to gain favor in the 1970s and are utilized today on 8 ranches in the valley. The ranchers attribute this shift to the advice of agency conservationists, one in particular who worked with them for nearly 30 years and whose opinions are highly regarded.

\section{Monitoring and Assessment}

Very little quantitative data on vegetation or range conditions are available from before 1970. Transects for monitoring vegetation composition, cover, and production have been installed on all but one ranch since that time, in cooperation with the Soil Conservation Service (now the Natural Resources Conservation Service). Transects are read every 1-3 years, and the data generally indicate improved perennial grass cover and production under the new rotational management systems. A recent watershed assessment, based on the rangeland health protocol, ${ }^{5}$ found "at risk" areas concentrated along incised drainages and in areas characterized by high levels of bare ground, Lehmann lovegrass, or mesquite. Patterns of rangeland health appeared to correlate more with elevation (virtually all the land above 4,500 ft [1,370 m] was deemed healthy) than with ranch boundaries.

\section{Motivations for Management}

In the Altar Valley, economic factors have played a large role in determining adoption of recommended management practices, but this role is far from simple. Most management practices conformed to contemporary recommendations from range science: water development, fencing, improved breeding, cow-calf production, continuous grazing (in the middle 20th century), brush control/seeding, rotational grazing (in the late 20th century), and monitoring. Only the last 3 , however, appear to have been prompted by range science itself rather than economic pressure or necessity. And in two cases - continuous grazing and brush control-the recommended practices are now most often viewed as having been faulty. Continuous grazing might have contributed to brush encroachment, and for late adopters, large-scale brush control was uneconomical (and is viewed now as having helped to drive some ranchers out of business altogether). Economic conditions appear to have undermined sustainable management at times when ranchers overstocked the range. Available evidence suggests excessive stocking was due to a combination of habit (ie, stocking based on past practice rather than current conditions) and economic pressure (principally the need to service debt). Finally, fire suppression was initially motivated (among ranchers) by the need to protect expensive fences.

Clearly, economic self-interest does determine management decisions, but it does not do so alone, and it does not necessarily lead to better management decisions. Whether economic incentives align with improved management depends on the time horizon of the rancher: debt, in particular, can force a short-term orientation even if long-term range degradation is a predictable result. The benefits of conservative stocking can take many years to develop in a semiarid setting such as the Altar Valley, whereas something much more expensive can be embraced if it promises rapid results (eg, mechanical brush control and seeding). A practice that is economical at one time, moreover, can become uneconomical later, yet continue to be implemented, whether because of a lag in reacting to changed circumstances or, as in the Buenos Aires case, because of larger economic and political circumstances that invert the calculus of costs and returns. It is also apparent that management decisions are taken in a larger context than that of the individual rancher's economic benefits and costs. Many practices in the Altar Valley-mesquite clearing, interior fencing, and rotational grazing, in particular-appear to have spread gradually, as ranchers waited to observe outcomes on neighboring ranches before deciding to adopt them on their own places. The long engagement and personal reputation of a single range conservationist appear to have been the key factors in more recent management decisions (rotational grazing and monitoring).

The views of Altar Valley ranchers of their present management practices and challenges are strongly informed by the history summarized above. They are acutely aware, for example, of the role of fire suppression in encouraging mesquite encroachment; they also understand that perennial grass dominance, if restored, will likely render their surface water tanks obsolete because run-off will not be sufficient to 
fill them. They recognize Lehmann lovegrass as less desirable forage than native grasses, but they also prefer it to what immediately preceded its introduction: mesquite, half-shrubs, and annual forbs. That overgrazing occurred during droughts and had lasting negative impacts on the range informs their greater willingness (relative to their predecessors) to stock conservatively and to reduce their herds when the rains fail.

The collective goals of today's Altar Valley ranchers are to conserve grasslands by restoring fire and to restore the valley's floodplains, which have been incised by a network of large arroyos that began after the drought of 1898-1904. The economic benefits of both goals are extremely long-term and uncertain: fire can inhibit further mesquite encroachment but will not likely reduce the present cover for decades, and the costs of floodplain restoration far exceed what livestock production can pay. Yet the ranchers are willing to rest areas from livestock for 2-4 years in order to build up fuel, burn, and allow recovery, and they have worked for more than a decade to persuade government agencies to restore the floodplains. Increasing forage production remains a goal, but faith in rapid or high-input means of accomplishing this has waned. Most valley ranchers have been ranching (there or elsewhere in southern Arizona) for decades, and they have learned not to expect rapid results from management interventions. Their goals suggest that the ranchers' mental model now involves a longer time horizon and a larger spatial scale than that of their predecessors. Further evidence of this is the emergence of the Altar Valley Conservation Alliance, a nonprofit organization of valley ranchers who came together in the early 1990s to try to gain input into fire management in the watershed. In recent years, however, a great deal of the Alliance's time and attention has been focused on other issues.

Unplanned residential development has boomed between the valley and Tucson in the past decade, and tract housing developments have been built no more than 15 minutes' drive from the valley's north end. The specter of subdivision undercuts the ranchers' resource goals in both practical and perceptual ways. Even a small number of houses would greatly complicate efforts to restore fire in the watershed, and housing built in the erstwhile floodplain (which no longer floods due to the arroyos, and where a great deal of private land is located) would preclude restoration of pre-entrenchment hydrological conditions. For these and other reasons, the ranchers feel collectively at risk: if any one major ranch were to convert to residential subdivision, all the others would be compromised in their ability to realize their resource goals. Perceptually, subdivision of any significance would also undermine the ranchers' collective sense of the valley as a working, rural landscape. Both their goals and their management practices indicate that they do still see the area in this way.

Yet the ranchers are equally determined to protect their property values, which they view as threatened by regulations that might limit or preclude the option of development. Federal measures to protect species listed under the Endangered Species Act (which have hindered fire planning) represent one such scenario; changes in county planning and zoning codes represent another. The ranchers' dependence on grazing leases makes them all the more determined to retain the option of realizing the equity contained in their private acres. Even if funds were available to pay for conservation easements, the ranchers would be unlikely to sell without greater assurance of continued access to the leased lands for grazing. From the ranchers' perspective, all three scenarios share a common source: the political power of environmental groups who oppose all ranching in the West. Regardless of the merits of this perception - the reality is too complex to review here-it makes collaborating with environmentalists, which Huntsinger and Hopkinson ${ }^{6}$ identify as essential to sustaining Western range landscapes, extremely difficult.

The contradiction between a commitment to ranching in the Altar Valley and a determination to protect property values inflated by the potential for development makes any simple elaboration of the ranchers' motivations impossible. Both values are upheld as paramount, in one case by the same individual in different contexts. The two are not really comparable: one is about use-value (ranching as life-way, culture, history, identity, family tradition) and the other is about exchange-value (what the ranch is worth in money at sale). They are mutually exclusive in practice-one must be given up to have the other-but they coexist in the minds and experiences of the ranchers themselves, who are trying to defend both.

\section{Conclusions}

Coppock and Birkenfeld ${ }^{7}$ and Peterson and Coppock ${ }^{8}$ suggest that changing socioeconomic and political conditions "may make isolated technical issues seem increasingly trivial" for ranchers. They further recommend greater "2-way communication" and "mutual learning" between rangeland users and researchers; that economic and political factors, rather than a lack of technology or information, might be the major constraints on management innovations; and that management investments might be episodic or ephemeral in response to socioeconomic circumstances.

The Altar Valley case supports these contentions. It is one particular landscape, and its relevance to other landscapes cannot be assumed. But its importance stands on its own: more than half a million acres, next door to a large and rapidly growing urban area, and endowed with a wealth of biological and other values. Moreover, many of the social, economic, and political processes driving the Altar Valley case are regional or national in scale, meaning that some commonalities with other areas can be expected.

It is clear that economic processes have been, and continue to be, strong drivers of management and land use decisions. But the character of these processes has changed with the rise of residential land use as a major competing land use. Previously, when livestock grazing was the only economical land use, ranchers' decisions focused on ranch management, and profitability was a major (albeit not the sole) criterion 
of evaluation. A relatively short time horizon appears to have accompanied this focus, however, leading to some decisions (eg, about stocking) that had negative long-term impacts. With the benefit of experience, most Altar Valley ranchers have adopted a longer-term perspective on ranch management and a landscape-scale vision of range resources, embedded within their understanding of the valley's nearly 125-year history in ranching.

These shifts have serious implications for range science. The scientific questions to which ranchers seek answers are less about livestock grazing and productivity than about other range resources and land uses. Much of the existing knowledge, moreover, is not sufficiently specific to satisfy the needs of ranchers or regulators. There are many studies of fire effects in desert grasslands, for example, and most everyone agrees that fires are a necessary ecological process there. But in the presence of a non-native, fire-adapted grass such as Lehmann lovegrass, and an endangered cactus that can be killed by fires, such a general conclusion cannot resolve regulatory and management disputes. Moreover, the audience for range science and range management information is larger than it once was. Ranchers and agency range conservationists are now joined by wildlife and other government officials, urban planners and environmentalists, recreationalists, and scientists of various kinds. Communication among these groups is uneven at best, and many seem dismissive of range science because they associate it with a narrow focus on livestock production. Research into these groups' interactions is needed both to help identify problems and to improve communication across social and scientific fields. All of these conclusions point to the need for greater understanding of working landscapes, and for methods that match the scale of research to the scale of the mental models and human-landscape interactions under study.
Author is Assistant Professor, Department of Geography, $507 \mathrm{Mc}$ Cone Hall MC 4740, University of California-Berkeley, Berkeley, CA94720-4740,nsayre@berkeley.edu.

\section{References}

1. Lynam, T., And M. S. Smith. 2003. Monitoring in a complex world: seeking slow variables, a scaled focus and speedier learning. In: N. Allsopp, A. R. Palmer, S. J. Milton, K. P. Kirkman, G. I. H. Kerley, C. R. Hurt, and C. J. Brown [eds.]. The VIIth International Rangeland Congress. Document Transformation Technologies, 26 July-1 August 2003, Durban, South Africa. p 617-629.

2. SAYre, N. F. 2000. Altar Valley watershed resource assessment, task three: investigate and document historic conditions. Arizona Water Protection Fund project no. 97-041. Tucson, AZ: Altar Valley Conservation Alliance. 53 p.

3. SAYre, N. F. 2002. Ranching, endangered species, and urbanization in the Southwest: Species of capital. Tucson, AZ: University of Arizona Press. 278 p.

4. Wooton, E. O. 1916. Carrying capacity of grazing ranges in southern Arizona. USDA Bulletin No. 367.40 p.

5. Pellant, M., P. Shaver, D. A. Pyke, and J. E. Herrick. 2000. Interpreting indicators of rangeland health. Version 3. USDI-BLM Technical reference 1734-6. 118 p.

6. Huntsinger, L., And P. Hopkinson. 1996. Sustaining rangeland landscapes: a social and ecological process. Journal of Range Management 49:167-173.

7. Coppock, D. L., And A. H. Birkenfeld. 1999. Use of livestock and range management practices in Utah. Journal of Range Management 52:7-18.

8. Peterson, R., and D. L. Coppock. 2001. Economics and demographics constrain investment in Utah private grazing lands. Journal of Range Management 54:106-114. 